\title{
Analysis of Water Quality in the Mandaong River for Development of Freshwater Fish Cultivation
}

\author{
M. Abjan Fabanjo ${ }^{1} \&$ Inayah $^{1}$ \\ ${ }^{1}$ Program Studi Manajemen Sumberdaya Perairan Fakultas Perikanan dan Kelautan Universitas Khairun \\ Ternate, Indonesia
}

Article History

Received : July $07^{\text {th }}, 2021$

Revised : August $28^{\text {th }}, 2021$

Accepted : September $20^{\text {th }}, 2021$

Published : October $09^{\text {th }}, 2021$

*Corresponding Author:

M. Abjan Fabanjo,

Program Studi Manajemen

Sumberdaya Perairan Fakultas

Perikanan dan Kelautan Universitas

Khairun Ternate.

Email:

dhani.haliyora@gmail.com
Abstract: The Mandaong River is a river flow that originates from the springs of Mount Sibela which until now has not been known with certainty the upstream point of the Mandaong River. This river flows through 3 (three) villages, namely Mandaong Village which is a downstream area, Makean Village Village and Papaloang Village which is an area of the Mandaong River body. Taking into account the position of the Mandaong River which flows from the mountains through plantations and settlements, it is estimated that it will receive some input from both natural processes and from the activities of the surrounding community such as bathing, washing, excavating sand, agriculture and settlements. Disposal of domestic waste, organic and inorganic waste so that there will be a decrease in the quality of river water in the form of physical, chemical and biological aspects. This study aims to determine the water quality of the Mandaong river based on physical, chemical and biological parameters and to determine the status of the water quality of the Mandaong river for the development of freshwater fish farming. The method of collecting water quality data on physical and chemical parameters was measured directly in the field and water samples were taken for further testing in the laboratory. For macroinvertebrate sampling by using nets /nets hand, the laying of nets is carried out systematically on the left, middle and right bank of the river at each predetermined station. Based on the results of measurements of the water temperature in the Mandaong river, it ranges from $25^{\circ} \mathrm{C}-27^{\circ} \mathrm{C}$, Flow Speed ranges from 1.02-2.06, River depth ranges from $45-97 \mathrm{~cm}$. and water $\mathrm{pH}$ ranged from 6.76-7.31, DO content ranged from 6.31-6.78, BOD content ranged from 0.10-5.63, nitrate content ranged from 0.361-2.068, phosphate content ranged from $4.506-6.753$, ammonia content in the range of 0.002 , detergent content in the range of 50. Family Biotic Index (FBI) values ranged from 3.36-4.16. The FBI index value shows that the water quality of the Mandaong River is in the very good category with the level of pollution not polluted by organic matter at stations 1 and 2, while at station 3 it is in the very good category with a slightly polluted level of organic matter. Based on the results of research and discussion, it can be concluded from this study that the testing of physical, chemical and biological parameters in research on the Mandaong river shows that the level of river water pollution is included in the very good category. Therefore, the water quality of the Mandaong River can be developed for freshwater fish farming activities.

Keywords: Water Quality, Mandaong River, Development, Aquaculture

\section{Pendahuluan}

Karakteristik aliran air sungai senantiasa bergerak dari daerah dataran tinggi ke arah yang lebih rendah, dimana kualitas airnya sangat di pengaruhi oleh aktivitas manusia pada daerah tangkapan aliran air sungai itu sendiri (Wiwoho, 2005). Kegiatan perikanan budidaya merupakan salah satu usaha dalam mengelola dan memanfaatkan potensi sumberdaya perikanan yang ramah lingkungan, dimana pemanfaatan aliran air sungai harus senantiasa memperhatikan syarat baku mutu kualitas air sebagai bagian dari upaya menjaga kelangsungan kegiatan budidaya dengan memenuhi persyaratan baik parameter fisik, kimia dan biologi (Anjelina, 2018). 
Fauzia dan Suseno (2020) menyataan bahwa kondisi kualitas perairan dari beberapa parameter fisika dan kimia seperti suhu, $\mathrm{pH}, \mathrm{DO}, \mathrm{BOD}$, kecerahann dan salinitas menjadi syarat penting yang berpengaruh pada pertumbuhan dan perkembangan serta tingkat produksi organisme akuatik. Sementara pengukuran kualitas air melalui parameter biologi dapat dilakukan dengan menganalisis struktur komunitas organisme yang hidup di dalam perairan tersebut. Salah satu organisme invertebrata yang hidup di dasar perairan dapat menjadi indicator kualitas peraiaran di daerah aliran sungai dan danau (Mahanal, 2019). Amizera et al, (2015) menambahkan bahwa biota makroinvertebrata lebih mudah terpengaruh oleh adanya perubahan lingkungan karena sifatnya yang menetap dan sulit menghindari adanya perubahan kondisi perairan sungai.

Sungai Mandaong merupakan salah satu aliran sungai yang titik hulunya belum diketahui hingga saat ini yang bersumber dari mata air gunung Sibela. Aliran sungai ini melintasi 3 (tiga) desa, yaitu Desa Mandaong yang merupakan daerah hilir, Desa Kampung Makean dan Desa Papaloang yang merupakan daerah badan Sungai Mandaong. Secara administratif wilayah Sungai Mandaong berbatasan dengan Desa Labuha di bagian Utara, Desa Kampung Makean di bagian Timur, Desa Tembal di bagian Selatan dan Laut di bagian Barat. Sungai Mandaong ini dimanfaatkan oleh Pemerintah Kabupaten Halmahera Selatan sebagai sumber baku air bersih yang dikelola oleh PDAM dan juga dimanfaatkan warga setempat untuk berbagai macam kegiatan seperti penggunaan air untuk keperluan rumah tangga, mandi, mencuci, galian pasir, pertanian dan sebagainya. dengan adanya aktivitas masyarakat tersebut, diperkirakan akan terjadinya penurunan kualitas air.

Untuk itu perlu dilakukan suatu kajian tentang karakterisitk kualitas air pada daerah aliran sungai untuk mengetahui kondisi kualitas air sungai, sehingga dapat dilakukan berbagai upaya baik kebijakan dan bentuk pengelolaan agar aliran sungai tersebut dapat dimanfaatkan sesuai persyaratan peruntukannya.

\section{Bahan dan Metode}

\section{Waktu dan Tempat}

Kegiatan Penelitian ini dilaksanakan di Sungai Mandaong Kecamatan Bacan Selatan Kabupaten Halmahera Selatan. dilaksanakan pada hari minggu tanggal 13 Februari 2021.

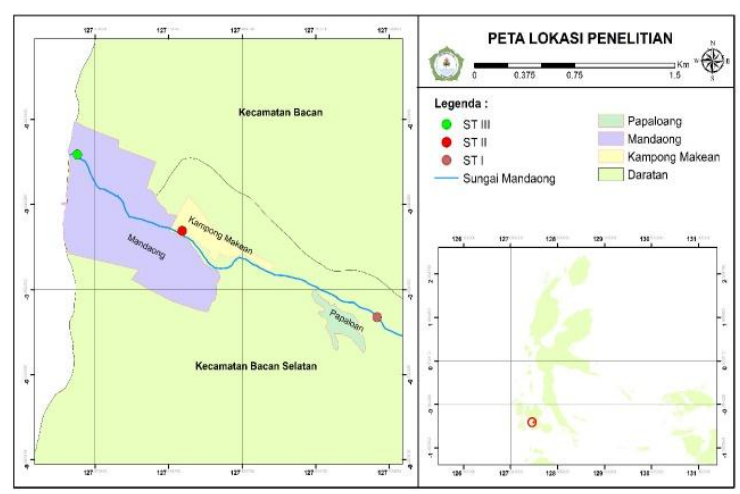

Gambar 1. Peta lokasi penelitian

\section{Alat dan Bahan}

Alat yang digunakan dalam penelitian ini adalah $\mathrm{pH}$ meter, DO meter, botol sampel, meteran roll, tongkat berskala, bola pingpong, tali rafia, stopwach, jaring hand net, kamera, dan alat tulis. Sedangkan bahan yang digunakan dalam penelitian ini adalah larutan $\mathrm{H}_{2} \mathrm{SO}_{4}$, akuades, dan makroinvertebrata.

\section{Metode penelitian}

Jenis metode yang digunakan dalam penelitian ini adalah metode deskriptif dan eksperimen, dimana metode deskriptif diarahkan untuk menganalisis dan menyajikan data secara sistematik sehingga dapat lebih mudah untuk dipahami, sementara metode eksperimen digunakan dalam penguumpulan data di lapangan yang kemudian dilanjutkan dengan menganalisis sample di laboratorium.

\section{Prosedur pengambilan data}

Pengukuran parameter fisika kimia perairan di lakukan pengukuran langsung di lapangan seperti suhu, $\mathrm{pH}, \mathrm{DO}$, dan kecepatan arus. Kemudian dilakukan pengambilan sampel air untuk tahapan pengukuran lanjutan di laboratorium seperti parameter BOD, nitrat, fosfat, detergen dan amoniak.

Untuk Pengambilan sampel makroinvertebrata digunakan jaring/hand net. Peletakan jaring di lakukan secara sistematis di bagian tepi kiri, tengah dan tepi kanan sungai pada setiap stasiun yang telah ditentukan, setelah sampel makroinvertebrata ditemukan kemudian di identifikasi dengan buku identifikasi (Merritt and cummins, 1996).

\section{Analisiss data}

a. Kondisi kualitas air Parameter Fisik-Kimia yaitu: Suhu, pH, DO, BOD, Nitrat, Fosfat, Deterjen, Amonia dan kecepatan arus kemudian 
dibandingkan dengan ketentuan baku mutu air kegiatan budidaya berdasarkan PP No. 82 tahun 2001 kelas II.

b. Kualitas air Sungai berdasarkan Makroinvertebrata Family Biotic Index (FBI) adalah penghitungan indeks kualitas air yang dikembangkan oleh Hilsenhoff (1988) berdasarkan nilai toleransi (ketahanan terhadap perubahan lingkungan) dari tiaptiap famili. Menurut Arisandi (2012) menyebutkan bahwa perhitungan nilai indeks biotik makroinvertebrata bentik dengan Modified Family Biotic Index (FBI) telah banyak digunakan untuk mengindikasikan tingkat pencemaran organik di perairan, dimana tiap family makroinvertebrata memiliki skor tertentu yang menunjukan tingkat toleransi terhadap pencemaran organik. Arisandi (2012) menambahkan pula bahwa perhitungan nilai indeks biotik menggunakan rumus sebagai berikut:

$$
\mathrm{FBI}=\sum_{i=1}^{i=n} \frac{x_{i} \cdot t_{i}}{N}
$$

Keterangan:

FBI = nilai indeks makroinvertebrata bentik

$\mathrm{i}=$ urutan kelompok famili yang menyusun komunitas makroinvertebrata

$x_{i}=$ jumlah individu kelompok famili ke-i

$t_{i}=$ tingkat toleransi kelompok famili ke-i

$\mathrm{N}=$ jumlah seluruh individu yang menyusun komunitas makroinvertebrata.

Interpretasi nilai biotik indeks untuk menentukan tingkat pencemaran organik dilakukan dengan mengikuti ketentuan yang ada seperti yang tertera pada Tabel berikut.

Tabel 1. Klasifikasi Kualitas Air berdasarkan FBI

\begin{tabular}{|c|c|c|}
\hline$\overline{\text { FBI }}$ & Kualitas Air & $\begin{array}{c}\text { Tingkat Pencemaran } \\
\text { Organik }\end{array}$ \\
\hline $0,00-3,75$ & $\begin{array}{c}\text { Amat sangat } \\
\text { bagus }\end{array}$ & $\begin{array}{l}\text { Tidak tercemar bahan } \\
\text { organik }\end{array}$ \\
\hline $3,76-4,25$ & Sangat bagus & $\begin{array}{c}\text { Sedikit tercemar bahan } \\
\text { organik }\end{array}$ \\
\hline $4,26-5,00$ & Baik & $\begin{array}{c}\text { Kemungkinan agak } \\
\text { tercemar }\end{array}$ \\
\hline $5,01-5,75$ & Sedang & Tercemar sedang \\
\hline $5,76-6,50$ & Agak buruk & Tercemar agak berat \\
\hline $6,51-7,25$ & Buruk & Tercemar berat \\
\hline & Iruk sel & 192 \\
\hline
\end{tabular}

Sumber: (Hilsenhoff 1988) daalam (Kahirun et al., 2019).

\section{Hasil dan Pembahasan}

\section{Hasil parameter fisik-kimia perairan}

Tabel 2. Hasil pengukuran parameter fisika kimia

\begin{tabular}{|c|c|c|c|c|}
\hline \multirow[t]{2}{*}{ No } & \multirow[t]{2}{*}{ Parameter } & \multicolumn{3}{|c|}{ Stasiun } \\
\hline & & 1 & 2 & 3 \\
\hline 1 & Suhu & $25^{\circ} \mathrm{C}$ & $25^{\circ} \mathrm{C}$ & $27^{\circ} \mathrm{C}$ \\
\hline 2 & $\begin{array}{l}\text { Kedalama } \\
\text { n Sungai }\end{array}$ & $45 \mathrm{~cm}$ & $97 \mathrm{~cm}$ & $80 \mathrm{~cm}$ \\
\hline 3 & $\begin{array}{l}\text { Lebar } \\
\text { Sungai }\end{array}$ & $13,5 \mathrm{~m}$ & $15 \mathrm{~m}$ & $13 \mathrm{~m}$ \\
\hline 4 & $\begin{array}{l}\text { Kecepatan } \\
\text { Arus } \\
\text { Sungai }\end{array}$ & $1,02 \mathrm{~m} / \mathrm{d}$ & $1,07 \mathrm{~m} / \mathrm{d}$ & $\begin{array}{l}2,06 \\
\mathrm{~m} / \mathrm{d}\end{array}$ \\
\hline 5 & $\mathrm{pH}$ & 6,87 & 7,31 & 6,76 \\
\hline 6 & DO & $6,24 \mathrm{mg} / \mathrm{l}$ & $6,87 \mathrm{mg} / \mathrm{l}$ & $\begin{array}{l}6,7 \\
\mathrm{mg} / 1\end{array}$ \\
\hline 7 & BOD & $0,10 \mathrm{mg} / \mathrm{l}$ & $5,60 \mathrm{mg} / \mathrm{l}$ & $\begin{array}{l}54,63 \\
\mathrm{mg} / 1\end{array}$ \\
\hline 8 & Nitrat & $\begin{array}{l}0,361 \\
\mathrm{mg} / \mathrm{l}\end{array}$ & $\begin{array}{l}1,938 \\
\mathrm{mg} / \mathrm{l}\end{array}$ & $\begin{array}{l}2,068 \\
\mathrm{mg} / \mathrm{l}\end{array}$ \\
\hline 9 & Fosfat & $\begin{array}{l}6,753 \\
\mathrm{mg} / 1\end{array}$ & $5,60 \mathrm{mg} / \mathrm{l}$ & $\begin{array}{l}4,506 \\
\mathrm{mg} / 1\end{array}$ \\
\hline 10 & Deterjen & $50 \mu \mathrm{g} / \mathrm{l}$ & $50 \mu \mathrm{g} / \mathrm{l}$ & $50 \mu \mathrm{g} / 1$ \\
\hline 11 & Amonia & $\begin{array}{l}0,002 \\
\mathrm{mg} / \mathrm{l}\end{array}$ & $\begin{array}{l}0,002 \\
\mathrm{mg} / \mathrm{l}\end{array}$ & $\begin{array}{l}0,002 \\
\mathrm{mg} / \mathrm{l}\end{array}$ \\
\hline
\end{tabular}

\section{Parameter fisika}

Suhu.

Berdasarkan hasil pengukuran suhu di Sungai Mandaong pada tiga stasiun diperoleh suhu di daerah hulu hingga hilir berkisar antara $25-27^{\circ} \mathrm{C}$ (gambar 5). Suhu tinggi berada pada stasiun 3 yaitu $27^{\circ} \mathrm{C}$ sedangkan suhu terendah berada pada stasiun 1 dan 2 yaitu $25^{\circ} \mathrm{C}$. Tingginya suhu pada stasiun 3 disebabkan pada saat pengukuran suhu kondisi langit cerah sekitar pukul 03:00 WIT, ketinggian \pm 2 meter dari permukaan laut, dengan tingkat kedalaman yang rendah yaitu $45 \mathrm{~cm}$ dan merupakan kawasan terbuka sehingga permukaan perairan langsung terkena oleh sinar matahari. Rendahnya suhu pada stasiun 1 dan 2 disebabkan pada waktu pengambilan sampel masih dipagi hari dan kondisi cuaca mendung sekitar pukul 09:00-12:20 WIT, dengan ketinggian \pm 72 meter pada stasiun 1 dan stasiun 2 memiliki ketinggian \pm 11 meter dari permukaan laut, dengan kedalaman sungai 80$97 \mathrm{~cm}$ dan merupakan kawasan yang terdapat banyak tumbuhan dan pohon-pohon besar di pinggiran sungai sehingga penyinaran matahari tidak terkenal langsung pada badan sungai. Kecilnya perbedaan suhu perairan sungai Mandaong dari stasiun 1 sampai stasiun 3 disebabkan karena perairan tersebut merupakan 
perairan yang mengalir, sehingga pengadukan air dapat terjadi setiap waktu. Suhu perairan Sungai Mandaong masih sesuai untuk kehidupan ikan air tawar. Adanya nilai suhu dapat di lihat pada Gambar 2.

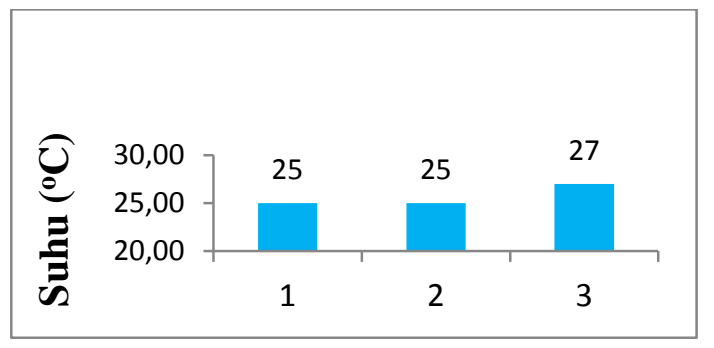

Gambar 2. Nilai suhu pada ketiga stasiun

\section{Lebar dan kedalaman sungai}

Hasil pengukuran lebar dan kedalaman Sungai Mandaong pada stasiun 1 memiliki lebar 13 meter dan kedalaman $80 \mathrm{~cm}$, stasiun 2 memiliki lebar 15 meter dan kedalaman $97 \mathrm{~cm}$, dan stasiun 3 memiliki lebar 13.5 meter dan kedalaman $45 \mathrm{~cm}$.

Lebar dan kedalaman sungai biasanya dipengaruhi oleh keadaan pasang surut suatu perairan, ketika kondisi pasang maka lebar dan kedalaman sungai akan bertambah, hal ini diakibatkan volume air yang meningkat dibandingkan ketika surut, berdasarkan pengukuran dapat dikatakan bahwa lebar dan kedalaman sungai berpengaruh terhadap karakteristik fisika sungai. Sungai yang lebar dan dangkal mendapatkan cahaya matahari lebih banyak sehingga suhu air sungai meningkat. Selain itu lebar dan kedalaman sungai juga mempengaruhi kecepatan arus sungai. sungai yang dalam dan lebar memiliki kecepatan aliran yang lebih besar (Subekti, 2015). Nilai lebar dan kedalaman sungai Mandaong dapat di lihat pada Gambar 3 dan 4.

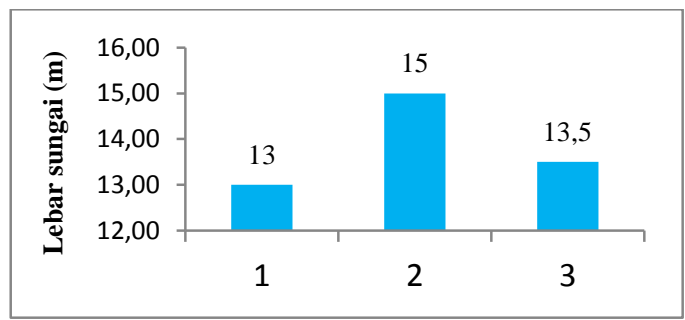

Gambar 3. Lebar sungai

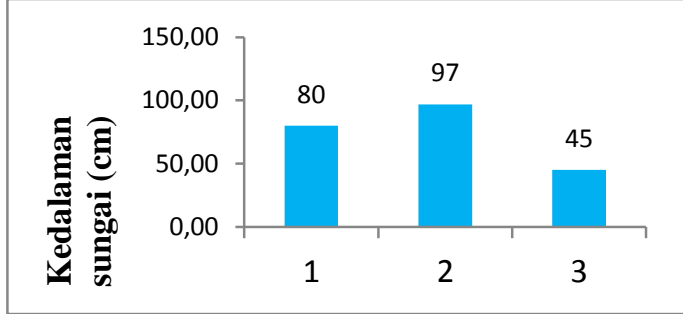

Gambar 4. Kedalaman sungai

\section{Kecepatan aliran sungai}

Hasil pengukuran kecepatan arus Sungai Mandaong dari tiga stasiun memiliki kecepatan arus berkisar antara 1.02-2.06 m/s (gambar 5). kecepatan arus dapat dipengaruhi oleh keberadaan angin, kemiringan, kedalaman, kesuburan kadar sungai dan substrat yang terdapat didasar perairan. Substrat ini dapat berupa lumpur, pasir, atau batu. kecepatan arus dapat dibedakan menjadi empat kelompok yakni : 1) Kecepatan arus 0-25 cm/det berarus lambat, 2) kecepatan arus $25-50 \mathrm{~cm} /$ det berarus sedang, 3) kecepatan arus $50-100 \mathrm{~cm} / \mathrm{det}$ berarus cepat dan 4) kecepatan arus $>100 \mathrm{~cm} / \mathrm{det}$ sangat cepat (Pratama et al, 2015)

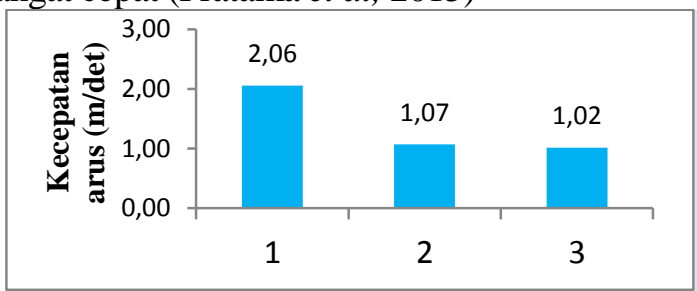

Gambar 5. Kecepatan arus

\section{Parameter kimia pH Air}

Nilai pH di Sungai Mandaong dapat dilihat pada gambar 9 menunjukkan bahwa dari stasiun 1 sampai stasiun 3 masih sesuai dengan baku mutu kelas II yang mengacu pada PP no. 82 tahun 2001 yaitu $\mathrm{pH}$ yang ditolerir untuk baku mutu kelas II berada pada kisaran 6-9, untuk pH di badan Sungai Mandaong berkisar antara 6,767,31. $\mathrm{pH}$ pada perairan Sungai Mandaong masi bersifat netral dan layak digunakan untuk kegiatan budidaya ikan. Sesuai dengan pernyataan Barus, (2001) dalam Suryanti et al., (2013) setiap spesies memiliki toleransi yang berbeda terhadap $\mathrm{pH}$. Nilai $\mathrm{pH}$ ideal bagi kehidupan biota air tawar umumnya berkisar 6,5-7,35. Adanya nilai $\mathrm{pH}$ di sungai Mandaong dapat dilihat pada gambar 6. 


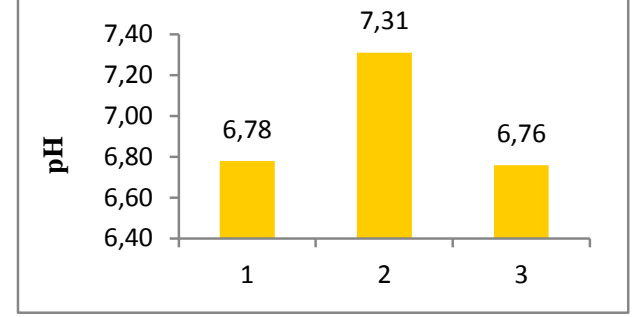

Gambar 6. pH air

\section{Parameter DO (Dissolved Oxygen)}

Hasil pengukuran oksigen terlarut (DO) pada aliran air Sungai Mandaong di stasiun 1 diperoleh nilai 6,24 mg/l, di stasiun 2 diperoleh 6,78 $\mathrm{mg} / \mathrm{l}$ dan di stasiun 3 diperoleh $6,7 \mathrm{mg} / \mathrm{l}$. Nilai DO pada sungai Mandaong masih dalam kondisi normal bahkan termasuk cukup baik. Kandungan oksigen terlarut pada aliran sungai Mandoang masih tergolong baik berdasarkan ketentuan baku mutu PP 82 Tahun 2001 yang mensyaratkan kadar oksigen terlarut minimum adalah $6,0 \mathrm{mg} / \mathrm{l}$ untuk air kelas satu, 4,0 mg/l untuk air kelas dua dan 3,0 mg/l untuk air kelas tiga.

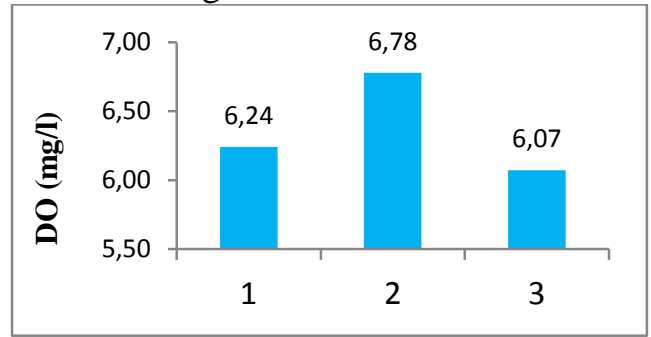

Gambar 7. Kandungan Oksigen terlarut

\section{Parameter BOD (Biochemical Oxygen Demand)}

Berdasarkan hasil analisis nilai BOD air Sungai Mandaong pada stasiun 1 diperoleh nilai 0,01 $\mathrm{mg} / \mathrm{l}$, stasiun 2 dengan nilai $5,60 \mathrm{mg} / \mathrm{l}$, dan stasiun 3 dengan nilai $5,63 \mathrm{mg} / \mathrm{l}$ (gambar 11). Nilai BOD pada stasiun 2 dan 3 menunjukan angka yang lebih tinggi bila dibandingkan dengan stasiun 1 hal ini di sebabkan karena adanya bahan- bahan organik yang berasal dari limbah domestik dan limbah lainnya. Menurut Rahayu dan Tontowi, (2009) menjelaskan bahwa pembungan atau masukknya limbah dari permukiman penduduk dan lahan pertanian menjadi salah satu sebab tingginya kandungan BOD pada aliran sungai. Sementara nilai BOD pada stasiun 2 dan 3 lebih tinggi bila di bandingkan dengan peruntukan air kelas satu yaitu $2 \mathrm{mg} / \mathrm{l}$. Namun untuk peruntukan air kelas dua, tiga dan empat masih tergolong baik. Menurut PP No 82 tahun 2001 bahwa nilai BOD untuk air kelas satu, dua, tiga dan empat adalah $2 \mathrm{mg} / \mathrm{l}, 3 \mathrm{mg} / \mathrm{l}, 6$ dan $12 \mathrm{mg} / \mathrm{l}$.

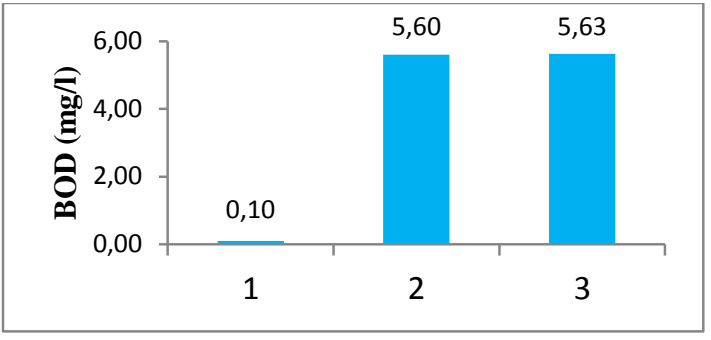

Gambar 8. Kandungan BOD

\section{Parameter kandungan nitrat}

Hasil uji kadar Nitrat (NO3) di Sungai Mandaong pada stasiun 1 yaitu $0.361 \mathrm{mg} / \mathrm{l}$, stasiun 2 yaitu $1.938 \mathrm{mg} / \mathrm{l}$ dan stasiun 3 yaitu $2.068 \mathrm{mg} / \mathrm{l}$ (gambar 8). Kandungan nitrat pada aliran sungai Mandaong masih tergolong rendah. Namun demikian aliran air sungai Mandaong masih tergolong baik untuk digunakan kegiatan budidaya perikanan. Ini menguatkan dugaan bahwa sangat sedikit polutan yang masuk ke perairan sungai Mandaong. Hal ini mungkin masih sedikitnya kegiatan masyarakat disekitar sungai baik pertanian, peternakan maupun aktiftas sehari-hari.

Berdasarkan ketentuan dalam PP 82 Tahun 2001, bahwa kandungan kadar nitrat 10 mg/l untuk air bersih

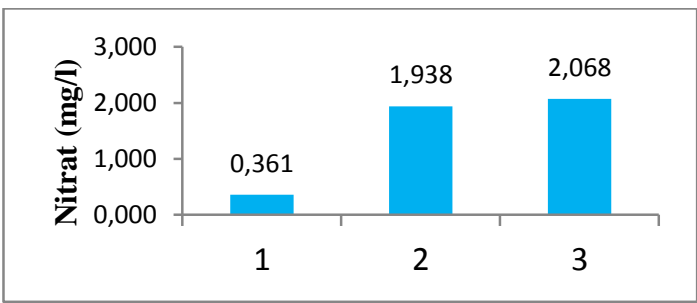

Gambar 9. Kandungan nitrat

\section{Parameter fosfat}

Hasil uji kandungan fosfat di sungai Mandaong berkisar antara 4,506-6,753 mg/l (gambar 9). Tingginya nilai fosfat di perairan sungai Mandaong diduga akibat tingginya penggunaan deterjen dan sejenisnya oleh masyarakat yang beraktifitas di sekitar muara sungai seperti mandi dan mencuci. Kemudian juga diduga berasal dari penggunaan pupuk oleh aktifitas pertanian dan perkebunan yang berada di dekat pinggir sungai.

Peraturan Pemerintah Nomor 82 tahun 2001 memberikan standar kadar fosfat peruntukan air kualitas satu, dua dan tiga sebesar $0,2 \mathrm{mg} / \mathrm{l}, 02 \mathrm{mg} / \mathrm{l}$ dan $1 \mathrm{mg} / \mathrm{l}$. Dan peruntukan air kelas empat sebesar $5 \mathrm{mg} / \mathrm{l}$. 


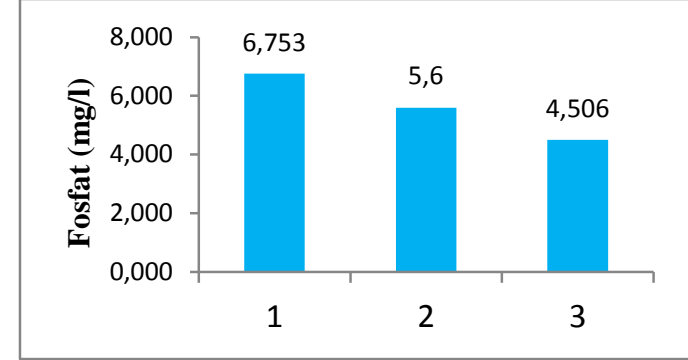

Gambar 10. Kandungan fosfat

\section{Parameter amoniak}

Hasil analisis kandungan amoniak pada Sungai Mandaong pada ketiga stasiun memiliki nilai $0,002 \mathrm{mg} / \mathrm{l}$ (gambar14). Perairan Sungai Mandaong memiliki kadar ammonia rendah dan layak digunakan untuk kegiatan budidaya. Kadar amoniak yang baik bagi kehidupan ikan air tawar kurang dari 1 ppm. Apabila kadar amoniak telah melebihi $1,5 \mathrm{ppm}$, maka perairan tersebut telah terjadi pencemaran. Menurut PP No. 82 Tahun 2001 (kelas II) bahwa batas maksimum amoniak untuk kegiatan perikanan bagi ikan yang peka $\leq$ $0,02 \mathrm{mg} / \mathrm{l}$.

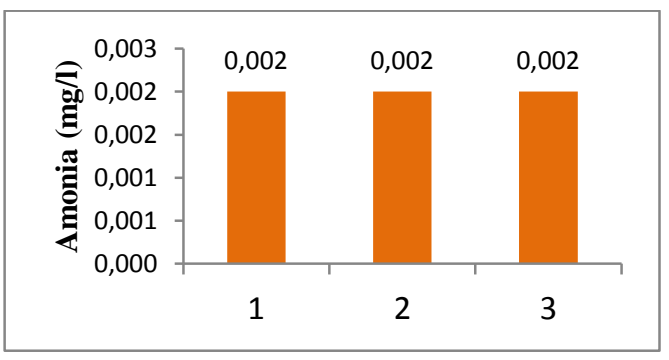

Gambar 11. Kandunga amonia

\section{Parameter deterjen}

Hasil pengukuran deterjen di sungai Mandaong pada ketiga stasiun menunjukkan nilai $50 \mu \mathrm{g} / \mathrm{l}$. nilai ini masih di bawah kisaran ambang batas baku mutu PP No. 82 Tahun 2001 (kelas II) yaitu $200 \mu \mathrm{g} / \mathrm{l}$, Perairan Sungai Mandaong memiliki kadar deterjen rendah dan layak digunakan untuk kegiatan budidaya. Melihat situasi di Sungai Mandaong banyak masyarakat menggunakan deterjen untuk kegiatan sehari-hari sebagai salah satu akibat daripada perkembangan budaya masyarakat yang cenderung terus membutuhkan kelengkapan alat-alat sebagai kebutuhan sekunder dan menimbulkan masalah penurunan kualitas air, namun berdasarkan hasil analisis nilai deterjen di Sungai Mandaong masi berada di bawa ambang batas baku mutu.

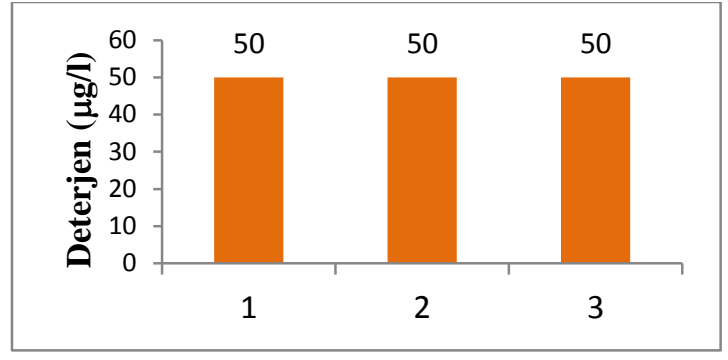

Gambar 12. Kandunga deterjen

\section{Pengamatan parameter biologi}

\section{Hasil makroinvertebrata yang ditemukan di sungai mandaong}

Hasil penggolongan makroinvertebrata yang terdapat ditiap stasiun dapat dilihat pada tabel 3 sebagai berikut:

Tabel 3. Hasil makroinvertebrata yang didapatkan pada sungai Mandaong.

\begin{tabular}{|c|c|c|c|c|c|}
\hline \multirow[t]{2}{*}{ No } & \multirow[t]{2}{*}{ Ordo dan Family } & \multicolumn{3}{|c|}{ Stasiun } & \multirow{2}{*}{$\begin{array}{c}\text { Jumlah } \\
\text { Individu } \\
\text { Total }\end{array}$} \\
\hline & & 1 & 2 & 3 & \\
\hline & Decapoda & & & & \\
\hline 1 & $\begin{array}{l}\text { Atydae } \\
\text { Ephemeroptera }\end{array}$ & 3 & 1 & 1 & 5 \\
\hline 2 & $\begin{array}{l}\text { Baetidae } \\
\text { Trichoptera }\end{array}$ & 1 & 2 & 0 & 3 \\
\hline 3 & $\begin{array}{l}\text { Hydropsychidae } \\
\text { Hemiptera }\end{array}$ & 1 & 4 & 0 & 5 \\
\hline 4 & Veliidae & 2 & 1 & 1 & 4 \\
\hline 5 & $\begin{array}{l}\text { Gerridae } \\
\text { Coleoptera }\end{array}$ & 1 & 1 & 0 & 2 \\
\hline 6 & $\begin{array}{l}\text { Elmidae } \\
\text { Diptera }\end{array}$ & 2 & 2 & 1 & 5 \\
\hline 7 & $\begin{array}{l}\text { Muscidae } \\
\text { Plecoptera }\end{array}$ & 1 & 1 & 1 & 3 \\
\hline 8 & $\begin{array}{l}\text { Perlodidae } \\
\text { Amphipoda }\end{array}$ & 27 & 18 & 7 & 52 \\
\hline 9 & Oligochaeta & 2 & 1 & 1 & 4 \\
\hline 10 & $\begin{array}{l}\text { Hydracarina } \\
\text { Basommatophora }\end{array}$ & 0 & 2 & 4 & 6 \\
\hline 11 & $\begin{array}{l}\text { Ancylidae } \\
\text { Neotaenioglossa }\end{array}$ & 1 & 1 & 1 & 3 \\
\hline 12 & Hydrobiidae & 1 & 2 & 2 & 5 \\
\hline & $\begin{array}{l}\text { Jumlah Total } \\
\text { Individu }\end{array}$ & 42 & 36 & 19 & 97 \\
\hline & jumlah Ordo & 10 & 10 & 8 & 10 \\
\hline & Jumlah Family & 11 & 12 & 9 & 12 \\
\hline
\end{tabular}

\section{Jumlah total makroinvertebrata}

Berdasarkan tabel 3 dan gambar 1 menunjukkan bahwa jumlah total individu makroivertebrata yang ditemukan di Sungai Mandaong yaitu 97 individu makroinvertebrata 
dengan perincian 42 individu ditemukan pada stasiun 1,36 individu ditemukan pada stasiun 2, dan 19 individu ditemukan pada stasiun 3. Jumlah total individu pada masing-masing stasiun dapat dilihat pada gambar 1.

$$
\text { Tingginya jumlah individu }
$$

makroinvertebrata pada stasiun 1 disebabkan karena kualitas perairan sungai Mandaong masih sangat baik untuk kehidupan makroinvertebrata, dengan ditemukan beberapa jenis makrozoobentos seperti dari family Baetidae, dan Perlodidae. Baikya kondisi perairan untuk berkembang biakkan jenis makroinvertebrata disebabkan karena kandungan nilai oksigen terlarut yang tinggi, suhu yang rendah serta terdapat banyak batuan dan dedaunan yang merupakan habitat yang cocok untuk perkembangbiakan makroinvertebrata tersebut. Widiyanto \& Sulistyarsi, (2016).

Maruru (2012), menambahkan bahwa apabila terdapat bahan pencemar dalam perairan maka biota yang sangat peka akan hilang karena tidak mampu bertahan hidup. Sebaliknya, biota yang sangat toleran akan tetap dapat hidup pada kualitas air yang buruk. Kelimpahan biota makroinvertebrata juga dipengaruhi oleh komponen lingkungan baik biotik maupun abiotik dalam suatu ekositem perairan. Jumlah total individu yang di temukan di sungai Mandaong dapat di lihat pada gambar 1.

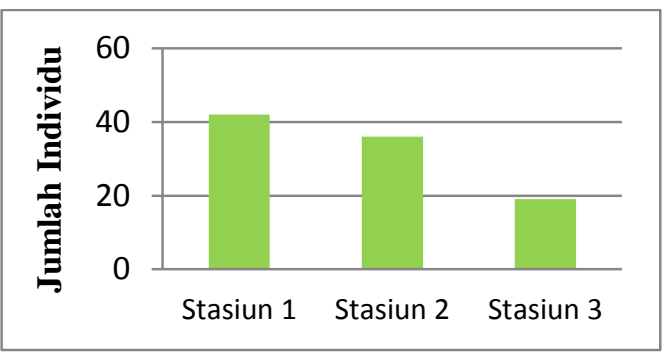

Gambar 1. Individu yang ditemukan di sungai Mandaong

\section{Family biotic index (FBI)}

Metode Family Biotic Index (FBI) merupakan metode perhitungan tingkat pencemaran suatu perairan dengan menggunakan indikator berupa keberadaan makroinvertebrata (invertebrata berukuran besar) berdasarkan familinya. Hasil analisis terhadap keberadaan makroinvertebrata berdasarkan FBI untuk setiap stasiun pengamatan dapat dilihat pada tabel 4-6.
Tabel 4. Hasil analisis FBI Makroinvertebrata pada Stasiun 1

\begin{tabular}{clccc}
\hline No & Family & $\begin{array}{c}\text { Jumlah } \\
\left(X_{i}\right)\end{array}$ & $\begin{array}{c}\text { Nilia } \\
\text { Toleransi } \\
\left(t_{i}\right)\end{array}$ & $X_{i} \cdot t_{i}$ \\
\hline 1 & Atydae & 3 & 6 & 18 \\
2 & Baetidae & 1 & 4 & 4 \\
3 & Hydropsych & 1 & 4 & 4 \\
& idae & 2 & 6 & 12 \\
4 & Veliidae & 1 & 5 & 5 \\
5 & Gerridae & 2 & 5 & 10 \\
6 & Elmidae & 1 & 6 & 6 \\
7 & Muscidae & 27 & 2 & 54 \\
8 & Perlodidae & 2 & 8 & 16 \\
9 & Oligochaeta & 1 & 6 & 6 \\
10 & Ancylidae & 1 & 6 & 6 \\
11 & Hydrobiidae & 1 & $\mathbf{4 2}$ \\
\hline \multicolumn{5}{c}{ Jumlah } \\
\hline \multicolumn{5}{c}{ Nilai FBI=3.36 } \\
\hline \multicolumn{5}{c}{}
\end{tabular}

Berdasarkan data tabel diatas nilai perhitungan Famili Biotic Indeks (FBI) untuk stasiun 1 termasuk dalam kategori kualitas sangat baik sekali dengan tingkat pencemaran tidak tercemar bahan organik.

Tabel 5. Hasil analisis FBI Makroinvertebrata pada Stasiun 2

\begin{tabular}{clccc}
\hline No & \multicolumn{1}{c}{ Family } & $\begin{array}{c}\text { Jumlah } \\
\left(\boldsymbol{X}_{\boldsymbol{i}}\right)\end{array}$ & $\begin{array}{c}\text { Nilia } \\
\text { Toleransi } \\
\left(\boldsymbol{t}_{\boldsymbol{i}}\right)\end{array}$ & $\boldsymbol{X}_{\boldsymbol{i}} \cdot \boldsymbol{t}_{\boldsymbol{i}}$ \\
\hline 1 & Atydae & 1 & 6 & 6 \\
2 & Baetidae & 2 & 4 & 8 \\
3 & Hydropsychidae & 4 & 4 & 16 \\
4 & Veliidae & 1 & 6 & 6 \\
5 & Gerridae & 1 & 5 & 5 \\
6 & Elmidae & 2 & 5 & 10 \\
7 & Ancylidae & 1 & 6 & 6 \\
8 & Perlodidae & 18 & 2 & 36 \\
9 & Hydrobiidae & 2 & 6 & 12 \\
10 & Muscidae & 1 & 6 & 6 \\
11 & Oligochaeta & 1 & 8 & 8 \\
$\mathbf{1 2}$ & Hydracarina & 2 & 4 & 8 \\
\hline \multicolumn{5}{c}{ Jumlah } \\
\hline \multicolumn{5}{c}{$\mathbf{3 6}$} \\
\hline
\end{tabular}

Berdasarkan data tabel diatas nilai perhitungan Famili Biotik Indeks (FBI) pada stasiun 2 termasuk dalam kategori kualitas sangat baik dengan tingkat pencemaran tidak tercemar bahan organik. 
Tabel 6. Hasil analisis FBI Makroinvertebrata pada Stasiun 3

\begin{tabular}{|c|c|c|c|c|}
\hline $\begin{array}{l}\mathbf{N} \\
\mathbf{0}\end{array}$ & Family & $\begin{array}{l}\text { Jumla } \\
\text { h }\left(X_{i}\right)\end{array}$ & $\begin{array}{c}\text { Nilia } \\
\text { Toleransi } \\
\left(t_{i}\right)\end{array}$ & $X_{i} \cdot t_{i}$ \\
\hline 1 & Atydae & 1 & 6 & 6 \\
\hline 2 & Muscidae & 1 & 6 & 6 \\
\hline 3 & Veliidae & 1 & 6 & 6 \\
\hline 4 & Elmidae & 1 & 5 & 5 \\
\hline 5 & $\begin{array}{l}\text { Perlodida } \\
\text { e }\end{array}$ & 7 & 2 & 14 \\
\hline 6 & $\begin{array}{l}\text { Hydracari } \\
\text { na }\end{array}$ & 4 & 4 & 16 \\
\hline 7 & Ancylidae & 1 & 6 & 6 \\
\hline 8 & $\begin{array}{l}\text { Oligochae } \\
\text { ta }\end{array}$ & 1 & 8 & 8 \\
\hline 8 & $\begin{array}{l}\text { Hydrobiid } \\
\text { ae }\end{array}$ & 2 & 6 & 12 \\
\hline & Jumlah & 19 & & 79 \\
\hline
\end{tabular}

Berdasarkan data tabel diatas nilai perhitungan Famili Biotik Indeks (FBI) pada stasiun 3 termasuk dalam kategori kualitas sangat baik dengan tingkat pencemaran sedikit tercemar bahan organik. Berdasarkan tabel 4-6 dapat dilihat bahwa pada stasiun 1, 2 dan 3 memiliki nilai indeks FBI sebesar 3,36, 3,53 dan 4,16 yang menandakan bahwa nilai kulitas air sungai Mandaong pada stasiun 1 dan 2 masih sangat baik sekali dan tingkat pencemaran tidak tercemar bahan organik, sedangkan pada stasiun 3 nilai kualitas air juga masih sangat baik dengan tingkat pencemaran sedikit tercemar bahan organik pada perairan tersebut. Hal ini dibuktikan dengan ditemukannya jenis makroinvertebrata yang memiliki sifat intoleran terhadap pencemar pada stasiun 1 dan 2 seperti famili dari Perlodidae (nilai 2) sehingga dapat dikatakan bahwa makroinvertebrata jenis tersebut merupakan bioindikator perairan yang belum tercemar.

Makroinvertebrata jenis ini dapat berkembang baik pada lokasi tersebut karena perairan tersebut memiliki nilai oksigen terlarut yang tinggi, suhu yang rendah serta terdapat banyak batuan dan dedaunan yang merupakan habitat yang cocok untuk perkembangbiakan makroinvertebrata tersebut. Maruru (2012), menambahkan bahwa apabila terdapat bahan pencemar dalam perairan maka biota yang sangat peka akan hilang karena tidak mampu bertahan hidup. Sebaliknya, biota yang sangat toleran akan tetap dapat hidup pada kualitas air yang buruk.

\section{Kesimpulan}

Berdasarkan hasil penelitian dan pembahasan, maka dari penelitian ini dapat disimpulkan bahwa Pengujian parameter fisika, kimia dan biologi pada penelitian di sungai Mandaong menunjukkan bahwa tingkat pencemaran air sungai termasuk dalam kategori sangat baik. Oleh karena itu kualitas air pada Sungai Mandaong dapat dikembangkan untuk kegiatan budidaya ikan air tawar.

\section{References}

Amizera, S., Ridho, M. R., \& Saleh, E. (2015). Kualitas Perairan Sungai Kundur Berdasarkan Makrozoobentos Melalui Pendekatan Biotic Index Dan Biotilik. Maspari Journal: Marine Science Research, 7(2), 51-56. DOI: https://doi.org/10.36706/maspari.v7i2.2483. (Accessed on February 17, 2021).

Anjelina, L. L. (2018). Kajian Kualitas Air Sungai Lae Renun untuk Kesesuaian Budidaya Ikan Jurung (Tor Tambra) di Desa Sumbul Kabupaten Dairi Sumatera Utara.

https://repositori.usu.ac.id/handle/123456 789/9289. (Accessed on Mey 02, 2021).

Arisandi, P. (2012). Pengukuran Kualitas Air Hulu Daerah Aliran Sungai Kali Brantas Berdasarkan Keragaman Taksa Ephemeroptera, Plecoptera, and Trichoptera. In Prosiding Seminar Nasional Kimia Unesa (pp. 298-309). https://adoc.pub/pengukuran-kualitas-airhulu-daerah-aliran-sungai-kali-brant.html. (Accessed on April 02, 2021).

Mahanal. S. (2019). Pembelajaran Deteksi Kualitas Air Sederhana Dengan Indikator Biologi Bentos Makroinvertebrata. Kementerian Riset, Teknologi, Dan Pendidikan Tinggi. Universitas Negeri Malang. 82. Hal. http://repository.um.ac.id/id/eprint/908. (Accessed on Mey 05, 2021).

Maruru. S.M. (2012). Studi Kualitas Air Sungai Bone Dengan Metode Biomonitoring. [Skripsi]. Program Studi Kesehatan Masyarakat. Universitas Negeri Gorontalo. https://repository.ung.ac.id/skripsi/show/81 
1408109/studi-kualitas-air-sungai-bonedengan-metode-biomonitoring.html. (Accessed on Mey 15, 2021).

Merritt, R. W \& Cummins, K, W. (1996). An Introduction to the Aquatic Insects of North America. New York; Kendall/ Hunt Publishing Company.

Pratama.F.I., Umar.M.R., \& Andriani. I, (2015). Distrbusi Populasi dan Ekologi Ikan Medaka Oryzias Spp. Di Daerah Aliran Sungai Saddang, Sulawesi Selatan. https://core.ac.uk/reader/77624234. (Accessed on Maret 06, 2021).

Subekti, A.R. (2015). Studi Kelayakan Pengembangan Pembangkit Listrik Tenaga Minihidro di Desa Sukamaju Kabupaten Garut Jawa Barat. Jurnal Teknik Hidraulik. 6 (2): 105 - $116 . \quad$ DOI: https://doi.org/10.32679/jth.v6i2.515.

(Accessed on June 01, 2021).

Suryanti, Rudiyanti S. \& Sumartini S. (2013). Kualitas Perairan Sungai Seketak Semarang Berdasarkan Komposisi Dan Kelimpahan Fitoplankton. Journal of Management of Aquatic Resources. 2 (2): 38-45. DOI:https://doi.org/10.14710/marj.v2i2.4102. (Accessed on June 01, 2021).

Wiwoho (2005). Model Identifikasi Daya Tampung Beban Cemaran Sungai Dengan Qual2e (Study Kasus Sungai Babon). [Tesis]. Program Magister Ilmu Lingkungan. Universitas Diponegoro http://eprints.undip.ac.id/11485/ (Accessed on Mey 05, 2021).
Pemerintah, P., \& OTONOM, K. (2001). Peraturan Pemerintah Republik Indonesia Nomor 82 Tahun 2001. Tentang Pengelolaan Kualitas Air dan Pengendalian Pencemaran Air.

Rahayu, S. \& Tontowi (2009). Penelitian Kualitas Air Bengawan Solo Pada Saat Musim Kemarau. Jurnal Sumber Daya Air. 5 (2): 127-136.DOI:

https://doi.org/10.32679/jsda.v5i2.472. (Accessed on April 09, 2021).

Kahirun, Siwi. L. O, Surya. R. A, Erif. L. O, Yasin. A, \& Ifrianty (2019). Indikator Kualitas Air Sungai Dengan Menggunakan Makroinvertebrata Di Sungai Wanggu. Jurnal Ecogreen. 5 (1): 63-67. http://ojs.uho.ac.id/index.php/green/article/v iew/6053/4450. (Accessed on April 25, 2021).

Fauzia, S.R \& Suseno, S.H. (2020). Resirkulasi Air Untuk Optimalisasi Kualitas Air Budidaya Ikan Nila Nirwana (Oreochromis Niloticus). Jurnal Pusat Inovasi Masyarakat, 2 (5): 887-892.

https://jurnal.ipb.ac.id/index.php/pim/article /view/31741. (Accessed on January 21, 2021).

Widiyanto, J., \& Sulistyarsi, A. (2016). Biomonitoring kualitas air Sungai Madiun dengan bioindikator makroinvertebrata. Jurnal Penelitian LPPM (Lembaga Penelitian dan Pengabdian kepada Masyarakat) IKIP PGRI MADIUN, 4(1), 1-9. http://ejournal.unipma.ac.id/index.php/JPLPPM/article/view/395. (Accessed on Maret 13, 2021). 